\title{
The Impact of Monetary Policy and International Trade on Economic Growth and Inflation in ASEAN-4 Countries
}

\author{
Rini Dwi Astuti ${ }^{1^{*}}$, Didit Welly Udjianto ${ }^{2}$ \\ 1, 2 Universitas Pembangunan Nasional Veteran Yogyakarta, Indonesia \\ E-mail: ${ }^{1}$ rinidwiastuti@upnyk.ac.id, ${ }^{2}$ diditwelly@upnyk.ac.id
}

*Corresponding author

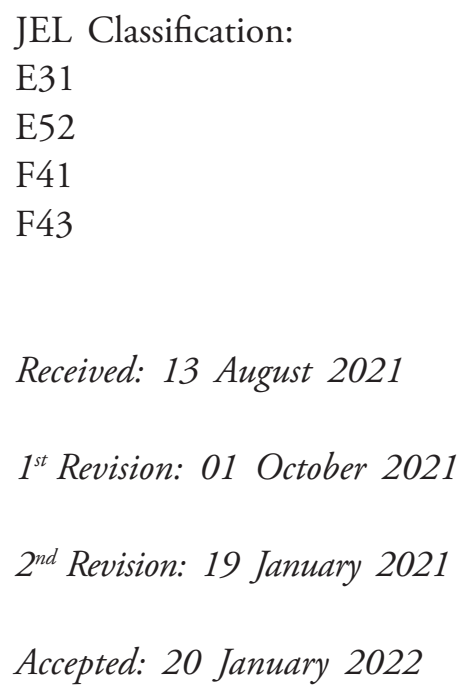

\begin{abstract}
Economic growth and price stability are the main goals of macroeconomics, among other goals. The central bank can influence the economy to achieve the desired condition through its monetary policy. This study aims to analyze the effect of monetary policy and international trade on economic growth and inflation in four ASEAN countries (Indonesia, Malaysia, the Philippines, and Thailand), using panel data analysis and vector autoregression. The impulse response results show that monetary policy with an interest rate policy instrument hurts economic growth in the short run and is positive in the long run. In the short run, an expansionary monetary policy has effectively accelerated economic growth, vice versa. International trade positively affects economic growth in ASEAN-4 countries in the short run and vice versa in the long run. Panel data analysis shows a price puzzle regarding the effect of interest rates on inflation. Likewise, the effect of international trade on inflation shows a positive influence. An increase in exports encourages an increase in aggregate demand and prices. The implications of the results of this study are the need for policy coordination monetary policy, trade policy, and policy in the real sector so that the effectiveness of monetary policy increases.
\end{abstract}

\section{Keywords:}

economic growth, inflation, monetary policy, international trade

\section{How to Cite:}

Astuti, R. D., \& Udjianto, D. W. (2022). The Impact of Monetary Policy and International Trade on Economic Growth and Inflation in ASEAN-4 Countries. Signifikan: Jurnal Ilmu Ekonomi, 11(1), 175-190. https://doi. org/10.15408/sjie.v11i1.22142. 


\section{INTRODUCTION}

The economy will experience a boom or recession in line with the business cycle: aggregate demand increases and drives prices up (Mankiw, 2010). High economic growth will ultimately hamper ongoing growth if not accompanied by price stability policies. How monetary policy promotes economic growth within price stability is an interesting discussion. As the monetary authority, the central bank faces obstacles in maintaining price stability by taking into account sustainable economic growth. The determinant of inflation is the supply and demand sides. Monetary policy stance through interest rates faces challenges in maintaining price stability because interest rates affect the economy from the demand side (Mishkin, 2016). Various studies that have been conducted related to the effect of monetary policy on economic growth show different results.

The central bank can carry out comprehensive monetary policy by increasing the money supply or lowering policy interest rates. An increase in the money supply (a decrease in interest rates) will cause an increase in prices because people hold large amounts of money, which encourages increased domestic demand. Empirical studies by Nouri \& Samimi (2011) in Iran, Onyeiwu (2012) in Nigeria, and Mahendra (2008) in Indonesia show that there is a positive effect of expansionary monetary policy on economic growth. Amrini et al. (2014) shows that an expansionary monetary policy driving inflation. Another research by Herlina (2013), Maslan (2017), Astuti \& Hastuti (2020) in Indonesia, Albu (2006) in Romania, and Obamuyi (2009) in Nigeria also found that monetary policy with an interest rate instrument was able to influence economic growth through its influence on investment and maintain price stability. However, a different result was shown by Amarasekara (2008) study, which found that contractionary monetary policy could not contain the inflation rate in Sri Lanka.

In a global era, a borderless world causes economic openness to influence economic growth and inflation. The broader market encourages economic growth that can disrupt price stability. In an increasingly integrated world economy, a country that is successful in its economy is a country that has succeeded in rapidly encouraging and maintaining the existence of international trade (Krugman, 2011). International trade is increasing due to the ease of transportation and information technology. Many benefits will be obtained through international trade, including obtaining goods that cannot be produced at home, benefiting from specialization, and technology transfer (Makhmutova \& Mustafin, 2017; Elias et al., 2018). However, international trade can become an obstacle to high economic growth if a growing number of imports is not accompanied by an increase in exports with a flat growth rate (Ijirshar, 2019). Reduced national income due to an increase in imports is more significant than the increase in national income due to an increase in exports will cause a decline in economic growth.

The positive relationship between international trade and economic growth is explained by the efficiency effect from rent-seek decreased and the benefits derived from external and internal economies of scale from international trade liberalization (Rodriguez \& Rodrik, 2001). This efficiency effect is considered the primary source of long-term economic 
growth from the new or endogenous growth theory, which predicts international trade and investment in physical capital and human capital can increase economic growth (Mogoe \& Mongale, 2014). International trade can increase product market share, investment efficiency, and positive externalities for firms (Sun \& Heshmati, 2010). An outward-oriented trade policy will specialize in economic sectors with economies of scale to increase efficiency through research and development, human capital accumulation, or learning by doing. This efficiency will encourage economic growth (Solomon \& Tukur, 2019).

Meanwhile, a study conducted by Fitriani (2019) proves that international trade, in this case, exports, positively influences economic growth. Likewise, with a study conducted by Solomon (2007). The data used in Indonesia's aggregate data from 1980 to 2006 covering gross domestic income, real exports, real imports, the real exchange rate of the rupiah against the dollar, the number of workers, and the crisis that hit Indonesia, with the ARDL (Autoregressive Distributed Lag) method. Real exports and real imports positively affect economic growth in the long term. The openness of international trade also boosts economic growth (Keho, 2017; Sun \& Heshmati, 2010) and decreases inflation in various countries (Leibovici, 2019; Gilchrist \& Zakrajsek, 2019; Mishra \& Topalova, 2007). Meanwhile, Moyo et al. (2017) and Elias et al. (2018) show that international trade cannot drive economic growth in Nigeria. The results of this study are supported by research by Aziz (2010) and Arslan et al. (2019), where trade openness encourages more imports to inhibit economic growth and impact inflation.

Research related to monetary policy and international trade on economic growth and inflation has not shown consistent results over time. Research by Astuti \& Hastuti (2020) in Indonesia, Awad (2011) in Egypt, and Adeoye \& Shobande (2017) in Nigeria found that expansive monetary policy with an interest rate instrument promotes growth. However, Amarasekara (2008) found that contractionary monetary policy is not effective in curbing the inflation rate in Sri Lanka. The openness of international trade as an engine of growth (Keho, 2017; Sun \& Heshmati, 2010) decreases inflation in various countries (Leibovici, 2019; Gilchrist \& Zakrajsek, 2019; Mishra \& Topalova, 2007). However, other studies have shown different results. International trade will drive economic growth (Elias et al., 2018; Moyo et al., 2017), where trade openness encourages imports to inhibit economic growth and impact inflation (Aziz, 2010; Arslan et al., 2019).

This study fills the research gap by combining factors that affect economic growth and inflation, in previous studies only analyzing factors that affect economic growth (Akinwale \& Grobler, 2019; Kallianiotis, 2019; Olamide et al., 2019a; Olamide et al., 2019b; Okoro et al., 2020; Solina \& Ocampo, 2020) and inflation (Dua \& Goel, 2021; Temitope, 2020; Tung, 2021) separately. In addition, this study uses panel data autoregression vector analysis, where previous research only focused on time series data analysis (Tadesse \& Melaku, 2019; Tahir \& Hayat, 2020; Tulasi, 2021) or panel data analysis (Younsi \& Nafla, 2019; Okoro et al., 2020). This study will re-confirm whether the monetary policy stance through interest rates is the right instrument in maintaining price stability and encouraging economic growth, particularly in Indonesia, Malaysia, the Philippines, and Thailand. Likewise, the more open the economy, whether to encourage 
economic growth through the expansion of the export market or hamper economic growth because the economy is flooded with imported goods which will reduce domestic production.

\section{METHODS}

The data used is panel data consisting of the countries of Indonesia, Malaysia, the Philippines and Thailand with a time series of quarterly years for the period 2008.Q12019.Q4. This study uses two panel data models as follows:

Model 1 growthit $=\alpha_{0}+\alpha_{1} \mathrm{ir}_{\mathrm{it}}+\alpha_{2}$ trade $+\mathrm{e}_{\mathrm{it}}$

$$
\alpha_{1}<0 ; \alpha_{2} \neq 0
$$

Model $2 \inf _{\mathrm{it}} \quad=\beta_{0}+\beta_{1} \mathrm{ir}_{\mathrm{it}}+\beta_{2}$ trade $+\varepsilon_{\mathrm{it}}$

$$
\beta_{1}<0 ; \beta_{2} \neq 0
$$

Where growth denotes economic growth (in percent), inf is inflation (in percent), ir is the central bank's interest rate (in percent), trade is the number of exports and imports (percentage of Gross Domestic Product), i is countries (Indonesia, Malaysia, Philippines, and Thailand), and $\mathrm{t}$ is a quarterly time series.

There are three models, the Pooled Least Square (Common Effect) method, the Fixed Effects model, and the Random Effects model. A testing stage is running to determine the most appropriate technique for estimating panel data regression, Chow test to choose between the Pooled Least Square (common) methods or the Fixed Effects technique. The second is the Hausman Test to choose between Fixed Effects or Random Effects techniques (Gujarati \& Porter, 2009).

In addition to using panel data analysis, this study uses analysis Vector Autoregressive (VAR) because VAR is equipped with an impulse response, the response of endogenous variables due to innovations (surprises) from other endogenous variables. By using impulse response analysis, the impact of changes in one of the independent variables can be simulated on future fluctuations in the dependent variable. VAR will only produce a reasonable estimate of the overall data used is stationary. Suppose the data is not stationary and VAR estimated at the level without including cointegration restrictions. In that case, the result will make parameters estimated in VAR are consistent, but parameter estimates are inefficient because information about the cointegration is ignored (long term relationship). An alternative solution is to use the Vector Error Correction Model (VECM) to produce more precise and efficient parameter estimates (Gujarati \& Porter, 2009; Gujarati, 2012). The VAR model in this study is as follows:

\section{Model 3:}

$$
\begin{aligned}
& \text { growth }_{i t}=\sum_{j=1}^{n} \alpha_{i} \text { ir }_{i t-j}+\sum_{k=1}^{n} \alpha_{j} \text { trade }_{i t-k}+e_{i t} \\
& \text { ir }_{i t}=\sum_{j=1}^{n} \alpha_{i} \text { growth }_{i t-j}+\sum_{k=1}^{n} \alpha_{j} \text { trade }_{i t-k}+e_{i t} \\
& \text { trade }_{i t}=\sum_{j=1}^{n} \alpha_{i} \text { growth }_{i t-j}+\sum_{k=1}^{n} \alpha_{i} \text { ir }_{i t-k}+e_{i t}
\end{aligned}
$$




\section{Model 4:}

$\inf _{i t}=\sum_{j=1}^{n} \alpha_{i} i r_{i t-j}+\sum_{k=1}^{n} \alpha_{j}$ trade $_{i t-k}+e_{i t}$

$i r_{i t}=\sum_{j=1}^{n} \alpha_{i}$ inf $_{i t-j}+\sum_{k=1}^{n} \alpha_{j}$ trade $_{i t-k}+e_{i t}$

trade $_{i t}=\sum_{j=1}^{n} \alpha_{i}$ inf $_{i t-j}+\sum_{k=1}^{n} \alpha_{i} i r_{i t-k}+e_{i t}$

\section{RESULT AND DISCUSSION}

The results of the stationarity test at the level of data or I (0) in Table 1 show that the variables of economic growth (growth) and international trade (trade) are significant at the significance level $(\alpha)$ of 5 percent. This is indicated by the statistical probability value of ADF, which is smaller than $0.05(\alpha=5 \%)$, meaning that the variable does not have a unit root, or it can be said that the data is stationary. Other variable data such as inflation (inf) and monetary policy interest rate (ir) have not shown data stationarity at the level. Thus, to find out the inflation variable data and policy interest rate will be stationary at what degree the next test stage is needed, the integration degree test at the first difference of degree one, I (1).

Table 1. Unit Root Test, I(0)

\begin{tabular}{cc}
\hline Variable & Probability ADF statistic \\
\hline growth & $0.0135^{*}$ \\
inf & 0.0776 \\
ir & 0.8586 \\
trade & $0.0421^{*}$ \\
\hline
\end{tabular}

Note: ${ }^{*}$ Significant at $a=5 \%$

The results of the integration degree level I (1) test in table 2 show that the inflation (inf) and the monetary policy interest rate (ir) have been stationary at the level first difference, where the statistical probability value of ADF is smaller than 0.05 . ( $\alpha=5 \%$ ).

Table 2. Unit Root Test, I(1)

\begin{tabular}{cc}
\hline Variable & Probability ADF statistic \\
\hline inf & $0.0000^{*}$ \\
ir & $0.0000^{*}$ \\
\hline
\end{tabular}

Note: ${ }^{*}$ Significant at $a=5 \%$

Cointegration testing was carried out to obtain long-term relationships between variables. The relationship that affects each other is seen through the cointegration of each variable itself. If there is cointegration between variables, then the relationship affects each other as a whole, and information is spread in parallel. The cointegration test model I using the Johansen method in table 3 shows three linear combinations of the model's 
variables with a (long term) cointegration relationship. This can be seen from the Fisher probability value statistic.

Table 3. Results of Cointegration

\begin{tabular}{ccccc}
\hline Hypothesized. & Fisher Stat. & \multicolumn{2}{c}{ Fisher Stat. } \\
\hline No. of CE(s) & (from trace test) & Prob & (from the max-eigen test) & Prob \\
\hline Model I & & & & \\
\hline None & 48.87 & 0.0000 & 37.21 & 0.0000 \\
At most 1 & 21.16 & 0.0067 & 18.09 & 0.0205 \\
At most 2 & 15.88 & 0.0441 & 15.88 & 0.0441 \\
\hline Model II & & & & \\
None & 26.88 & 0.0007 & 20.16 & 0.0097 \\
At most 1 & 14.09 & 0.0795 & 10.96 & 0.2042 \\
At most 2 & 15.31 & 0.0535 & 15.31 & 0.0535 \\
\hline
\end{tabular}

Model II cointegration test results in Table 3 using Johansen, it appears that the value of statistical probability Fisher is smaller than $0.05(\alpha=5 \%)$ at the Ho of None. This means an independent linear combination of the variables contained in the model. The alternative hypothesis that there is an integration relationship is acceptable.

The length test was optimum lag carrier out to eliminate the autocorrelation problem. So that by performing the optimum lag test, it is expected that autocorrelation problems will not arise. Determination of the optimum lag uses several information criteria as follows: Likelihood Ratio (LR), Schwarz Criterion (SC), Final Prediction Error (FPE), Akaike Information Criterion (AIC), Hannan Quinn (HQ).

So, according to the results of the optimum lag test in model I, which is summarized in table 4, it shows that Schwarz Criterion (SC) has a grace period of one with a significance level of 5\%, Hannan Quinn (HQ) has a grace period of two at a significance level of 5\%. In contrast, Likelihood Ratio Test (LR), Final Prediction Error (FPE), and Akaike Information Criterion (AIC), Hannan Quinn (HQ) has a grace period of five at the 5\% significance level. Thus, this study will use lag the optimum 5.

Based on the results of determining the optimum lag of Model II in table 4, at lag optimum 1, two criteria are proposed, namely Schwarz Criterion (SC) and Hannan Quinn (HQ). The rest shows the five of lag optimum, namely the Likelihood Ratio (LR), Final Prediction Error (FPE), and Akaike Information Criterion (AIC). Then, this research will use the lag optimum 5 .

Impulse Response Function is a method used to determine the response of an endogenous variable to a shock particular. Because the shock of the instance variables-i affects the variables-i was alone but transmitted to all other endogenous variables through the dynamic structure or the structure of lag thein the VAR. In other words, IRF measures 
the effect of a shock on the innovation of endogenous variables at that time and in the future. Meanwhile, IRF aims to isolate a shock to be more specific, which means that a variable can affect by shock a particular shock. If a variable cannot affect by shock, then the specific shock is not known, but shock in general.

Table 4. Determination of Optimum Lag

\begin{tabular}{|c|c|c|c|c|c|c|}
\hline \multicolumn{7}{|c|}{ Model I } \\
\hline Lag & LogL & LR & FPE & $\mathrm{AIC}$ & SC & HQ \\
\hline 0 & -905.1997 & NA & 292.0688 & 14.19062 & 14.25746 & 14.21778 \\
\hline 1 & -340.6878 & 1093.742 & 0.049647 & 5.510747 & $5.778125^{*}$ & 5.619384 \\
\hline 2 & -325.2599 & 29.16835 & 0.044915 & 5.410312 & 5.878223 & $5.600426^{*}$ \\
\hline 3 & -315.9907 & 17.09020 & 0.044754 & 5.406104 & 6.074549 & 5.677697 \\
\hline 4 & -300.2677 & 28.25222 & 0.040338 & 5.301058 & 6.170036 & 5.654128 \\
\hline 5 & -285.9162 & $25.11517^{*}$ & $0.037170^{*}$ & $5.217440^{*}$ & 6.286952 & 5.651988 \\
\hline 6 & -280.7131 & 8.861468 & 0.039548 & 5.276768 & 6.546812 & 5.792793 \\
\hline 7 & -278.3868 & 3.853032 & 0.044058 & 5.381043 & 6.851621 & 5.978547 \\
\hline 8 & -277.8539 & 0.857635 & 0.050538 & 5.513342 & 7.184453 & 6.192323 \\
\hline \multicolumn{7}{|c|}{ Model II } \\
\hline Lag & LogL & LR & FPE & AIC & SC & $\mathrm{HQ}$ \\
\hline 0 & -864.2003 & NA & 153.9110 & 13.55000 & 13.61685 & 13.57716 \\
\hline 1 & -240.6199 & 1208.187 & 0.010395 & 3.947185 & $4.214563^{*}$ & $4.055822^{*}$ \\
\hline 2 & -227.7899 & 24.25667 & 0.009794 & 3.887342 & 4.355253 & 4.077457 \\
\hline 3 & -215.8329 & 22.04566 & 0.009358 & 3.841139 & 4.509584 & 4.112732 \\
\hline 4 & -211.9294 & 7.014089 & 0.010145 & 3.920772 & 4.789750 & 4.273842 \\
\hline 5 & -188.4104 & $41.15834^{*}$ & $0.008101^{*}$ & $3.693912^{*}$ & 4.763423 & 4.128460 \\
\hline 6 & -182.9138 & 9.361320 & 0.008580 & 3.748653 & 5.018698 & 4.264679 \\
\hline 7 & -175.5374 & 12.21713 & 0.008833 & 3.774022 & 5.244601 & 4.371526 \\
\hline 8 & -167.9005 & 12.29075 & 0.009067 & 3.795320 & 5.466431 & 4.474301 \\
\hline
\end{tabular}

Note: * Significant at $a=5 \%$

The response of economic growth to shock monetary policy can be seen in Figure 1a, were from the first to the second period, it has decreased and shows a negative trend. In the third period, the response of economic growth to the shock of monetary policy increased but remained on a negative trend. Then in the fourth period, it declined again. Nuru (2020) obtained the same result, an increase in interest rate will be responded to by an increase in economic growth. In the short term, expansionary monetary policy is effective in stimulating output. In the fifth period, it began to increase. Then, the sixth period increased and showed a positive trend. In the seventh 
period, it experienced a decline. However, it was still on a positive trend. However, in the tenth period, the response to economic growth due to monetary policy shock disappeared. In the long term, monetary policy through changes in policy interest rate instruments is no longer effective in driving output increases. This result is by Kallianiotis' research (2019) in the United States, the decline in the benchmark interest rate has no impact on actual output, especially in the post-global crisis period where interest rates are close to zero.

Figure 1. IRF Model I

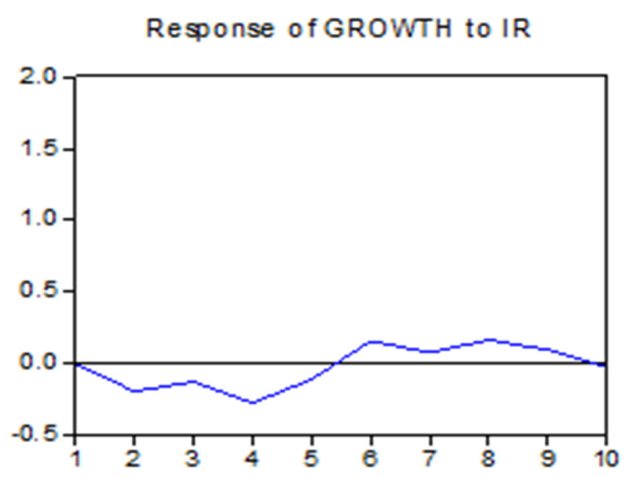

(a)

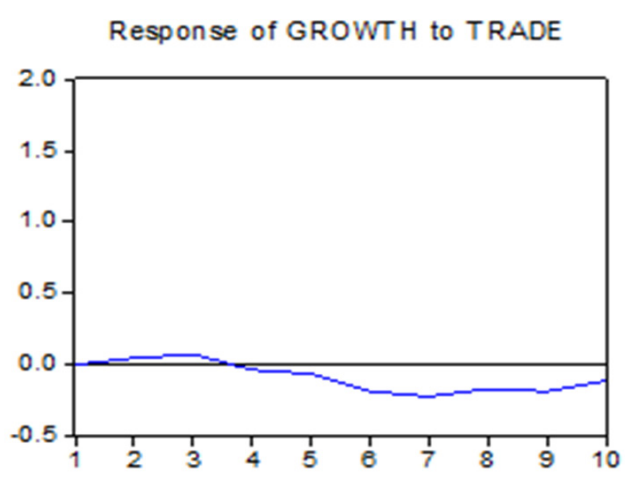

(b)

Figure 1 shows the responses of economic growth to international trade shocks. The responses are positive trends from the first to the third period. In the fourth to seventh period, it has decreased until the trend of response to economic growth was negative. In the eighth period, it increased to the tenth period, but the response of economic growth to international trade still showed a negative trend. In the short term, economic openness reflected in the increase in international trade will encourage economic growth, but not long term. Economic openness worsens the economy in the four ASEAN countries. The inability of international trade as an engine of growth is due to the dominance of imported goods in the local market and the high dependence on imported raw materials. The study of Okoro et al. (2020) found that trade between Economic Community of West African States (ECOWAS) countries can encourage economic growth in the region, but international trade of ECOWAS countries with the world has no effect on economic growth. The same result is shown by Akinwale \& Grobler (2019), international trade affects economic growth in South Africa in the short term. Younsi \& Nafla’s (2019) study shows that economic openness can encourage economic growth in developed countries but not in developing countries. Research by Raza et al. (2018) in the United Arab Emirates shows that exports positively affect economic growth. However, imports harm economic growth, and Tahir \& Hayat's (2020) research shows a positive effect of trade openness on economic growth in Brunei Darussalam. 
Figure 2. IRF Model II

Response of INF to IR

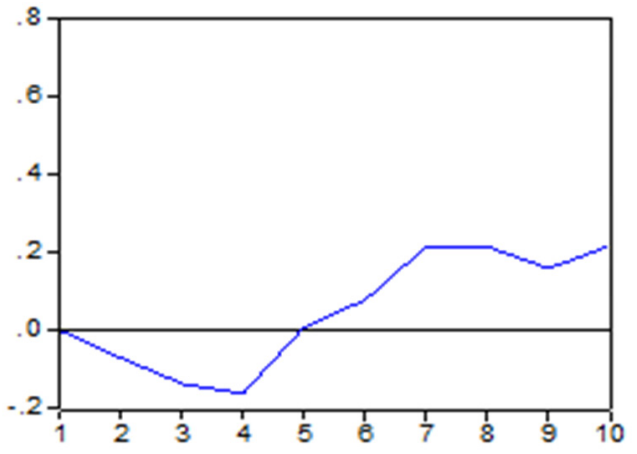

(a)
Response of INF to TRADE

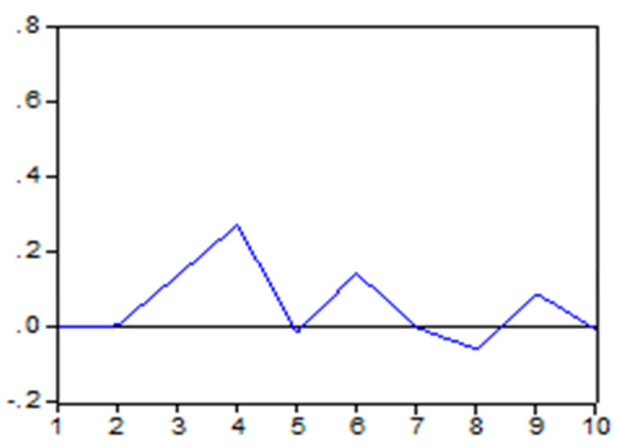

(b)

The inflation response to shocks monetary policy in the first to fourth periods decreased with a negative trend because the IRF line was below the horizontal line. It is increasing and shows a positive trend, at the fifth to the seventh period. In the eighth period, it was relatively stable, showing no change. In the ninth period, it experienced a decline, but the trend still showed positive, and in the tenth period, it experienced a positive trend again (Figure 2a.). This study indicates that in the first five periods, the contractionary monetary policy effectively overcame the problem of inflation, where an increase in policy interest rate could reduce inflation. However, in a more extended period, where the economy has experienced adjustment, contractionary monetary policy becomes counterproductive because the increase in interest rate drives inflation higher.

An increase in policy interest rate can reduce inflation in the short term, but there is a price puzzle in the long term. This result follows Nuru (2020). The contractive monetary policy effectively restraining the inflation rate, but if this policy is carried out in the long term, it will encourage higher inflation. An increase in interest rate means an increase in the cost of capital which will cause a decrease in company profits. Companies that want to keep profits at the same level will charge higher product prices. Dua \& Goel (2021) show a long-term relationship between inflation and the factors that influence it, including the interest rate. A determinant of inflation from the supply side implies that the monetary policy stance through interest rate may reduce its effectiveness in the long term because the cause of inflation does not only come from the demand side. Macroeconomic policy coordination between monetary policy and policy in the real sector is a must to maintain price stability, in addition to the importance of maintaining public expectations of inflation (Tulasi et al., 2021). Other studies show the same result, and monetary policy can influence inflation (Tung, 2021). However, Temitope (2020) shows different results, where interest rates have no effect on inflation in South Africa.

The inflation response to shock the international trade in the first to second periods experienced a positive trend because the IRF line was right on the horizontal line (Figure $2 \mathrm{~b})$. The inflation response to international trade shock has increased positively in the second to fourth periods. Then the inflation response fell back in the fifth period giving 
a negative trend. In the sixth period, the inflation response to shock the international trade increased again with a positive trend. Furthermore, in the seventh to eighth period, the inflation response to the shock of international trade has decreased by showing a negative trend, again increasing in the ninth period towards a positive trend. Inflation tends to respond positively to economic openness. The broader market causes an increase in aggregate demand and prices. In Leibovici's research (2019), an open economy has a more robust response to inflation expectations than a closed economy. The Gilchrist \& Zakrajsek (2019) study in the United States found different results that an increase in international trade reduced price fluctuations. Based on the test results with the Chow test models I and II (Table 5), it can be seen that the probability value of cross-section $F$ is 0.0000 , meaning that $\mathrm{H}_{0}$ is rejected or $\mathrm{Ha}$ accepted. In the chow test, $\mathrm{H}_{\mathrm{a}}$ is the Fixed Effect Model.

Table 5. Chow Test Results

\begin{tabular}{|c|c|c|c|c|c|c|c|}
\hline \multicolumn{4}{|c|}{ Model I } & \multicolumn{4}{|c|}{ Model II } \\
\hline \multicolumn{4}{|c|}{ Redundant Fixed Effects Test } & \multicolumn{4}{|c|}{ Redundant Fixed Effects Test } \\
\hline \multicolumn{4}{|c|}{ Equation: EQ01_GROWTH } & \multicolumn{4}{|c|}{ Equation: EQ02_INF } \\
\hline \multicolumn{4}{|c|}{ Test cross-section Fixed Effects } & \multicolumn{4}{|c|}{ Test cross-section Fixed Effects } \\
\hline Effects Test & Statistic & d.f & Prob & Effects Test & Statistic & d.f & Prob \\
\hline Cross-Section F & 10.072041 & $(3,154)$ & 0.0000 & Cross-section F & 13.118147 & $(3,154)$ & 0.0000 \\
\hline $\begin{array}{l}\text { Cross-Section Chi- } \\
\text { Square }\end{array}$ & 28.665128 & 3 & 0.0000 & $\begin{array}{l}\text { Cross-section Chi- } \\
\text { square }\end{array}$ & 36.411583 & 3 & 0.0000 \\
\hline
\end{tabular}

The role of monetary authorities in maintaining financial stability, monitoring the capital flows, and sustaining economic growth becomes more challenging, especially after the excellent inflation period of 1970-1980 and the global financial crisis of 2007. Besides the additional challenges and triple mandate to maintaining the price and the financial and economic stability, containing inflation remains the most vital task. Maintaining price stability by containing inflation to a moderate rate has often been considered the most essential responsibility of central banks and monetary authorities. In pursuit of price stability, several countries have adopted the strategy of explicit inflation targeting (Pham et al., 2020).

After the chow test was carried out with the results that the Fixed Effect Model was the appropriate model for panel data regression, and then do the Hausman Test. The test determines whether the Fixed Effect Model or the Random Effect Model is most appropriate. Based on the test results with the test Hausman (table 6) for the model I show that the Chi-Square probability value is 0.1236 , meaning that $\mathrm{H}_{0}$ is accepted. Thus, $\mathrm{Ha}$ is rejected, so the Random Effect Model is appropriate for this panel data test. Model II shows that the Chi-Square probability value is 0.0000 , meaning that $\mathrm{H}_{0}$ is rejected. Then, the suitable model for this panel data of Model II is the Fixed Effect Model. 
Table 6. Hausman Test Results

\begin{tabular}{|c|c|c|c|c|c|c|c|}
\hline \multicolumn{4}{|c|}{ Model I } & \multicolumn{4}{|c|}{ Model II } \\
\hline \multicolumn{4}{|c|}{ Correlated Random Effects - Hausman Test } & \multicolumn{4}{|c|}{ Correlated Random Effects - Hausman Test } \\
\hline \multicolumn{4}{|c|}{ Equation: EQ01_GROWTH } & \multicolumn{4}{|c|}{ Equation: EQ02_INF } \\
\hline \multicolumn{4}{|c|}{ Test cross-section Random Effects } & \multicolumn{4}{|c|}{ Test cross-section Random Effects } \\
\hline Test Summary & $\begin{array}{l}\text { Chi-Sq. } \\
\text { Statistic }\end{array}$ & Chi-Sq. d.f. & Prob. & Test Summary & $\begin{array}{l}\text { Chi-Sq. } \\
\text { Statistic }\end{array}$ & $\begin{array}{l}\text { Chi-Sq. } \\
\text { d.f }\end{array}$ & Prob. \\
\hline $\begin{array}{l}\text { Cross-section } \\
\text { random }\end{array}$ & 4.181206 & 2 & 0.1236 & $\begin{array}{l}\text { Cross-section } \\
\text { random }\end{array}$ & 28.353731 & 2 & 0.0000 \\
\hline
\end{tabular}

Based on testing the monetary policy rate variable on economic growth, the probability value of the t-statistic is 0.0109 percent, and the coefficient value is negative, meaning that any change in the reference interest rate affects economic growth. As for the variable international trade on economic growth, the probability value of t-statistic is 0.7189 percent, so any changes in international trade do not affect economic growth (see table 7).

Table 7. Random Effect Model I and Fixed Effect Model II

\begin{tabular}{cccccc}
\hline \multicolumn{2}{c}{ Dependent Variable: Economic Growth } & \multicolumn{2}{c}{$\begin{array}{c}\text { Model II } \\
\text { Dependent Variable: Inflation }\end{array}$} \\
\hline Variable & Coefficient & $\begin{array}{c}\text { Probability } \\
\text { t-statistic }\end{array}$ & Variable & Coefficient & $\begin{array}{c}\text { Probability } \\
\text { t-statistic }\end{array}$ \\
\hline ir & -0.625686 & $0.0109^{*}$ & ir & 0.570458 & $0.0003^{*}$ \\
trade & -0.021289 & 0.7189 & trade & 0.260935 & $0.0000^{*}$ \\
\hline
\end{tabular}

Note: ${ }^{*}$ Significant at $a=5 \%$

The regression results of the monetary policy rate have a significant influence on economic growth with a regression coefficient of -0.625686, meaning that every 1 percent increase in the reference interest rate will result in a decrease in economic growth. By -0.62 percent. This means that every central bank raising interest rate will reduce economic growth because by increasing the reference interest rate, people will reduce consumption, preferring to save, and reduce credit loans to banks because of higher interest rates so that consumption and investment will decrease. Meanwhile, the international trade variable has no significant effect on economic growth, meaning that there is no effect when there is an increase or decrease in international trade on economic growth. Developing countries tend to have a small market share in the global market. The economy is driven more by the domestic market, so economic openness does not significantly impact output. The results of this panel data analysis support the research of Younsi \& Nafla (2019).

The test of the reference interest rate variable on inflation shows that the probability value of the t-statistic is 0.0003 percent, and the coefficient value is positive, meaning that every change in the reference interest rate affects inflation (table 7). In the international 
trade variable on inflation, the probability value of t-statistic is 0.0000 percent, meaning that every change in international trade has a significant effect on inflation.

The regression coefficient of the monetary policy rate is 0.570458 , meaning that every 1 percent increase in the reference rate will result in a change in the increase in inflation of 0.57 percent. This means that each central bank increases the policy rate, followed by an increase in inflation. The regression coefficient for international trade is 0.260935 , meaning that every 1 percent increase in international trade will result in changes in the increase in inflation of 0.26 percent. When an increase in international trade, export, and imports affects domestic prices, it can increase prices. This study is in line with Leibovici's (2019) research but differs from Aron \& Muellbauer (2007) research, where an increase in trade openness causes a decrease in the average inflation rate in South Africa.

From the policy perspective, the spillover effects of the global monetary policy shocks, if not properly understood and effectively managed, could pose difficulties to the domestic policy design in emerging economies as it can disrupt capital flows (Han $\&$ Wei, 2018). The study of the transmission of international monetary policy shock to emerging countries is not new. The literature shows that these shocks are transmitted to these economies through well known financial and trade channels, including interest rate, exchange rate, domestic credit, and asset price (Tumala et al., 2021). Adjustment to domestic and global economic conditions must be the primary concern of the central bank in order to maintain economic stability and promote sustainable economic growth. In an increasingly open economy, it causes a decrease in the effectiveness of monetary policy (Douch, 2019). The central bank is directed to use a price targeting policy framework to maintain price stability and encourage economic growth.

\section{CONCLUSION}

The study shows that the effectiveness of monetary policy in influencing output and prices in the four ASEAN countries only applies in the short term. The central bank can actively implement monetary policy to stimulate economic growth and overcome inflation. However, these policies cannot be long-term because they can be counterproductive, which will worsen the economy. International trade affects economic growth in the four ASEAN countries in the short term but not in the long term. An outward-looking-oriented policy can be a policy strategy that can encourage economic growth. However, an increasingly open economy will also increase market opportunities for imported goods in the long term. Increasing the competitiveness and efficiency of domestic production is the main requirement so that economic openness does not worsen the economy in the long term.

International trade variables concern examining exports and imports individually. An increasingly open economy, seen from the indicator of an increase in the share of international trade to GDP, shows a positive impact on economic growth in a relatively short time but can cause an increase in inflation. International trade policies are needed to increase the competitiveness of local products in the international market by considering the availability of local raw materials to limit the demand for imported goods, leading 
to price increases. Research variables are more concerned with the monetary policy transmission channel through the interest rate channel, where the policy interest rate will transmit to the real sector through the money market and banking interest rates. Further research can develop the models by adding variables and research objects not to be limited to only four countries in ASEAN.

\section{ACKNOWLEDGEMENT}

The authors would like to thank the Institute for Research and Community Service at Universitas Pembangunan Nasional Veteran Yogyakarta, Indonesia, for providing funds for this research.

\section{REFERENCES}

Adeoye, B., \& Shobande, A. O. (2017). Monetary Policy Transmission Mechanism and Macroeconomic Aggregates in Nigeria. Caleb Journal of Social and Management Sciences, 3(2), 115-134.

Akinwale, Y. O., \& Grobler, W. C. (2019). Education, Openness and Economic Growth in South Africa: Empirical Evidence from VECM Analysis. The Journal of Developing Areas, 53(1), 51-64.

Albu, L. L. (2006). Trends in the Interest Rate - Investment - GDP Growth Relationship. Romanian Journal of Economic Forecasting, 3, 5-13.

Amarasekara, C. (2008). The Impact of Monetary Policy on Economic Growth and Inflation in Sri Lanka. Central Bank of Sri Lanka Staff Studies, 38(2), 1-44.

Amrini, Y., Aimon H., \& Syofyan, E. (2014). Analisis Pengaruh Kebijakan Moneter terhadap Inflasi dan Perekonomian di Indonesia. Jurnal Kajian Ekonomi, 2(4), 1-29.

Aron, J., \& Muellbauer, J. (2007). Inflation dynamics and trade openness: with an application to South Africa. CSAE WPS/2007-11.

Arslan, Y., Contreras, J., Patel, N., \& Shu, C. (2019). How Has Globalization Affected Emerging Market Economies?. BIS Papers, 100, 27-55.

Astuti, R. D. \& Hastuti, S. R. B. (2020). Monetary Policy Transmission. JEQu, 10(1), 1-22.

Awad, I. L. (2011). The Monetary Transmission Mechanism in A Small Open Economy: The Case of Egypt. Journal of Economics and Business, 14(1), 73-96.

Aziz, M. D. Nusrate. (2010). Exchange Rates, International Trade, and Inflation: A Developing Economy Perspective. (Unpublished Thesis). University of Birmingham.

Douch, M. (2019). Monetary policy in a small open economy with imperfect passthrough. Atlantic Economic Journal, 47(4), 445-461.

Dua, P. \& Goel, D. (2021). Determinants of inflation in India. The Journal of Developing Areas, 55(2), 205-221.

Elias, IA, et.al (2018). Impact of International Trade on the Economic Growth of Nigeria. European Journal of Business and Management, 10(18), 22-30. 
Fitriani, E. (2019). Analysis of the Influence of International Trade on Indonesia's Economic Growth. Journal of Business Research and Management, 9(1), 18-26.

Gilchrist, S. \& Zakrajsek, E. (2019). Trade Exposure and the Evolution of Inflation Dynamics. Finance and Economics Discussion Series 2019, 007. Board of Governors of the Federal Reserve System. Washington.

Gujarati, D. N., \& Porter, D. C. (2009). Basic Econometrics. McGraw-Hill. Singapore.

Gujarati, D. N. (2012). Econometrics by Examples. Palgrave Macmillan. New York.

Han, X., \& Wei, S. J. (2018). International transmissions of monetary shocks: Between a trilemma and a dilemma. Journal of International Economics, 110, 205-219.

Herlina, D. (2013). Identification of Monetary Policy Transmission Mechanisms for 20002011. Journal of Performance, 17(2), 158-173.

Ijirshar, V. U. (2019). Impact of Trade Openness on Economic Growth among ECOWAS Countries: 1975-2017. CBN Journal of Applied Statistics, 10(1), 75-96.

Kallianiotis, I.N. (2019). Monetary policy, the Actual Cost of Capital, Financial Markets, and Real Economic Growth. Journal of Applied Finance \& Banking, 9(1), 75-118.

Keho, Y. (2017). The Impact of Trade Openness on Economic Growth: The Case of Cote d'Ivoire. Cogent Economics \& Finance, 5, 1-14.

Krugman, P. (2011). International Economics: Theory and Policy. Prentice-Hall. New Jersey.

Leibovici, F. (2019). International Trade Openness and Monetary Policy: Evidence from Cross-Country Data. Federal Reserve Bank of St. Louis Review, Second Quarter 2019, 101(2), 93-113.

Mahendra, A. (2008). Analysis of Monetary Policy and Its Impact on Indonesia’s Economic Growth. (Unpublished Thesis). The University of Northern Sumatra.

Makhmutova, D. I., \& Mustafin A. N. (2017). Impact of International Trade on Economic Growth. International Journal of Scientific Study, 5(6), 140-144.

Mankiw, N. G. (2010). Macroeconomics, Seventh Edition. Worth Publishers. New York.

Maslan J, 2017, Efektifitas Mekanisme Transmisi Kebijakan Moneter di Indonesia Melalui Jalur Suku Bunga. Jurnal Ilmiah Kohesi, 1(1), 43-58.

Mishkin, F. S. (2016). The Economics of Money, Banking, and Financial Markets. Pearson Education. London.

Misra, P., \& Topalova, P. (2007). How Does Globalization Affect Developing Countries? IMF Research, 8(3), 1-5.

Mogoe, S., \& Mongale, I. P. (2014). The Impact of International Trade on Economic Growth in South Africa: An Econometric Analysis. Mediterranean Journal of Social Sciences, 5(14), 60-66.

Moyo, C., Khobai, H., \& Kolisi, N. (2017). The Relationship between Trade Openness and Economic Growth: The Case of Ghana and Nigeria. MPRA Paper, 81317, 1-17.

Nouri, M., \& Samimi, A. J. (2011). The Impact of Monetary Policy on Economic Growth in Iran. Middle-East Journal of Scientific Research, 9(6), 740-743. 
Nuru, N. Y. (2020). The Dynamic Effects of Monetary Policy Innovations in Ethiopia. African Journal of Economic and Management Studies, 11(1), 169-180.

Obamuyi, T. M. (2009). An Investigation of the Relationship between Interest Rates and Economic Growth in Nigeria, 1970 - 2006. Journal of Economics and International Finance, 1(4), 93-98.

Okoro, A. S., Ujunwa, A., \& Ukemenam, A. (2020). Does Regional Trade Promote Economic Growth? Evidence from the Economic Community of West African States (ECOWAS). Journal of Economics and Development, 22(1), 131-147.

Olamide, E. G., \& Maredza, A. (2019b). A Dynamic Regression Panel Approach to the Determinants of Monetary Policy and Economic Growth: The SADC experience. African Journal of Economic and Management Studies, 10(3), 385-399.

Olamide, E. G., \& Maredza, A. (2019a). Regional effects of monetary policy on the economic growth of ecowas: An s-var approach. The Journal of Developing Areas, 53(1), 205-223.

Onyeiwu, C. (2012). Monetary Policy and Economic Growth of Nigeria. Journal of Economics and Sustainable Development, 3(7), 62-73.

Pham, T. A. T., Nguyen, T. T., Nasir, M. A., \& Duc Huynh, T. L. (2020). Exchange Rate Pass-through: A Comparative Analysis of Inflation Targeting \& Non-targeting ASEAN-5 Countries. Quarterly Review of Economics and Finance, 1-10.

Raza, S. A., Sbia, R., \& Al Rousan, S. (2018). Trade-growth Nexus and the Rolling Window Analysis in the United Arab Emirates. Journal of Asia Business Studies, 12(4), 469-488.

Rodriguez, F., \& Rodrik, D. (2001). Trade Policy and Economic Growth: A Skeptic's Guide to the Cross-National Evidence. NBER Macroeconomics Annual 2000, 15, 261-338.

Solina, A. M., \& Ocampo, L.V.G. (2020). Monetary policy indicators and economic growth in the Philippines 1986-2017. Review of Integrative Business and Economics Research, 9(1), 160-170.

Solomon, O. I., \& Tukur, M. U. (2019). Trade Openness and Economic Growth in the Developing Countries: Evidence from Nigeria. International Journal of Academic Research in Economics and Management Sciences, 8(3), 30-42.

Solomon, R. (2007). The Role of International Trade as One of Indonesia's Economic Growth Sources. Module. Department of Commerce of the Republic of Indonesia and Postgraduate Program of Economic Sciences Indonesia University.

Sun, P., \& Heshmati, A. (2010). International Trade and its Effects on Economic Growth in China. IZA Discussion Paper, No. 5151, 1-36.

Tadesse, T., \& Melaku, T. (2019). Analysis of the Relative Impact of Monetary and Fiscal Policies on Economic Growth in Ethiopia, using ARDL Approach to Cointegration: which Policy is more Potent?. Copernican Journal of Finance \& Accounting, 8(2), 87-115.

Tahir, M., \& Hayat, A. (2020). Does International Trade Promote Economic Growth? Evidence from Brunei Darussalam. Journal of Chinese Economic and Foreign Trade Studies, 13(2), 71-85. 
Temitope, L. A. L. (2020). Monetary Policy or Fiscal Policy, which One better Explains Inflation Dynamics in South Africa?. African Journal of Business and Economic Research, 15(1), 27-52.

Tulasi, G. et al. (2021). Understanding trend inflation in India: What do data speak?. IUP Journal of Applied Economics, 20(3), 57-71.

Tumala, M. M., Salisu, A. A., Atoi, N. V., \& Yaaba, B. N. (2021). International monetary Policy Spillovers to Emerging Economies in Sub-Saharan Africa: A global VAR analysis. Scientific African, 14, 1-10.

Tung, L. T. (2021). Fiscal Policy, Monetary Policy, and Price Volatility: Evidence from an Emerging Economy. Organizations and Markets in Emerging Economies, 12(1), 51-70.

Younsi, M., \& Nafla, A. (2019). Financial Stability, Monetary Policy, and Economic Growth: Panel Data evidence from Developed and Developing Countries. Journal of the Knowledge Economy, 10(1), 238-260. 